\title{
Epizootic mortality in the pilchard Sardinops sagax neopilchardus in Australia and New Zealand in 1995. I. Pathology and epizootiology
}

\author{
R. J. Whittington ${ }^{1, *}$, J. B. Jones ${ }^{2}$, P. M. Hine ${ }^{3}$, A. D. Hyatt ${ }^{4}$ \\ ${ }^{1}$ New South Wales Agriculture, Elizabeth Macarthur Agricultural Institute, Private Bag 8, Camden, New South Wales 2570. \\ Australia \\ ${ }^{2}$ Fisheries Department of Western Australia, Animal Health Laboratory, 3 Baron-Hay Court, South Perth, \\ Western Australia 6151, Australia \\ ${ }^{3}$ National Institute of Water and Atmospheric Research, PO Box 14-901, Wellington, New Zealand \\ ${ }^{4}$ CSIRO, Australian Animal Health Laboratory, PO Bag 24, Geelong, Victoria 3220, Australia
}

\begin{abstract}
A large-scale epizootic occurred in the Australasian pilchard Sardinops sagax neopilchardus between March and September 1995 over more than $5000 \mathrm{~km}$ of the Australian coastline and $500 \mathrm{~km}$ of the New Zealand coastline. Affected fish died within a few minutes of clinical signs of respiratory distress and death was associated with hypoxaemia and hypercapnea. Significant lesions were confined to the gills and comprised acute to subacute inflammation followed by bizarre epithelial hypertrophy and hyperplasia. The lesions were initially focal but progressed to become generalised over about $4 \mathrm{~d}$. Pathological changes in affected fish from western Australia, eastern Australia and New Zealand were similar, suggesting a common aetiology. The lesions were unlike those associated with ichthyotoxic algae, siliceous algae, physicochemical factors, fungi, bacteria, dinoflagellates, amoebae. other protozoa and metazoa. A herpesvirus was consistently present in gills of affected fish and absent from unaffected pilchards and is proposed as the aetiological agent. The rate of spread of the mortality front (approximately $30 \mathrm{~km} \mathrm{~d}^{-1}$ ) in relation to the migration rate of pilchards and prevailing currents suggests that a vector was involved. The disease may have been newly introduced into Australian waters
\end{abstract}

KEY WORDS: Clupeoidei - Pilchard - Sardinops sagax neopilchardus - Gill diseases - Pathology Epizootiology Mortality. Herpesvirus

\section{INTRODUCTION}

The Australasian pilchard Sardinops sagax neopilchardus is a prolific, small, pelagic, planktivorous fish of the suborder Clupeoidei which is found in waters of the continental shelves of Australia and New Zealand south of latitude $25^{\circ} \mathrm{S}$ (Fletcher 1990). Closely related species are found in waters off South Africa, South America, California and Japan (Fletcher 1990).

In 1995 an extraordinary epizootic affected schools of this species in Australasia. No other species of fish

·E-mail:whittir@agric.nsw.gov.au were affected. Mortalities on a massive scale commenced in March 1995 in central southern Australian coastal waters and spread in both easterly and westerly directions. Floating rafts of dead pilchards as large as $3 \mathrm{~km}$ by $1 \mathrm{~km}$ were observed and many tonnes of dead pilchards were washed ashore on nearby beaches. The epizootic was observed progressively over 4 mo along more than $5000 \mathrm{~km}$ of the Australian coastline, representing the total range of the species in Australia. A similar phenomenon commenced in northeastern New Zealand waters in June 1995, eventually affecting pilchards along $500 \mathrm{~km}$ of the coast. There have been no other progressive large-scale epizootics affecting pilchards in Australasia and to our knowl- 
edge this is the largest mortality event ever recorded in any fish species in terms of both numbers affected and geographic range.

Although oceanographic disturbances were suspected to be the cause of the epizootic in the first few weeks, it was soon clear that infectious disease would also need to be considered. This report details the results of the investigation undertaken by a network of institutions in Australia and New Zealand and provides strong evidence for an infectious aetiology. A companion paper (Hyatt et al. 1997) provides more details of a herpesvirus, which is the most likely aetiological agent.

\section{MATERIALS AND METHODS}

Occurrence and spread of disease. The occurrence and spread of the disease was monitored by observers at sea, along the coastline in inhabited areas and from aircraft. Observers included commercial fishermen, Government officers and members of the public in both countries. Data were collated for this report from information supplied with specimens submitted for laboratory examination and from the records of New South Wales Agriculture, New South Wales Fisheries. the Fisheries Department of Western Australia and the National Institute of Water and Atmospheric Research, New Zealand. Data for South Australia and Victoria were obtained from the Department of Primary Industries and Energy, Canberra. In Australia, the distance and elapsed time of the disease front from its origin were calculated as the shortest distance in $\mathrm{km}$ by sea from the site at which dead pilchards were thought to have been seen first (Anxious Bay, South Australia) and the time in days from the date of origin to the first date at each site at which dead pilchards were seen, respectively. Data analysis was carried out using SYSTAT.

Clinical signs. Affected and healthy pilchards were observed from the surface of the water, underwater by SCUBA divers, and also by viewing underwater video camera recordings.

Blood gas analysis. During the outbreak in Wellington Harbour, New Zealand, in September 1995, pilchards ( $\mathrm{n}=16$ ) that were $>11 \mathrm{~cm}$ total length and that were swimming listlessly at the surface were removed using a hand net. The tail was severed and blood was taken into heparinized $75 \times 1 \mathrm{~mm}$ capillary tubes (Drummond Scientific Company, Broomall, Pennsylvania, USA), chilled over ice, and pools of 2 samples were read on an AVL 995 automatic blood gas system analyser. Normal pilchards were sampled from Wellington Harbour in December 1995, 3 mo after the outbreak. Eight were caught by rod and line and placed immediately into seawater, taken to a laboratory aqua- rium and maintained for 1 to $5 \mathrm{~d}$ in a dimly lit environment. They were then removed one by one with minimal excitement and blood was sampled and processed as above. Results for the 2 groups were compared using a t-test assuming normality of the data.

Collection of specimens. The epizootic commenced in a relatively remote area and initially only a few opportunistic collections were made. Later, field staff were deployed at sea specifically to collect healthy, moribund and freshly dead fish. Healthy live pilchards were collected in purse-seine nets (Australia) or with rod and line (New Zealand). Affected fish were removed from the sea by dip netting. Whole fish were placed immediately on wet ice or wet ice/sea water slurry in insulated boxes, or into $10 \% \mathrm{v} / \mathrm{v}$ buffered neutral formalin or $10 \% \mathrm{v} / \mathrm{v}$ formalin in seawater. Some specimens were fixed directly in $2.5 \% \mathrm{v} / \mathrm{v}$ glutaraldehyde in filtered seawater. Fixation of specimens from some collections in Western Australia was delayed by u.p to an hour. In some instances one operculum was removed and/or the abdominal cavity was incised to allow more rapid penetration of fixative. Fish were transported to laboratories for examination within 24 h of collection.

Prospective investigations were undertaken in New South Wales (lluka) and Western Australia (Albany, Rottnest Island). Specimens were collected from schools of pilchards at these locations before the arrival of the mortality front, during the mortality event, and after the mortality front had passed.

Gross pathology and histopathology. Fish collected from New South Wales and from Bremer Bay, Western Australia, were subjected to a full necropsy. Gills, brain, skeletal muscle and viscera were examined histologically from up to 10 fish from each collection. Tissues were embedded routinely in paraffin wax, sectioned at $5 \mu \mathrm{m}$ and stained with haematoxylin and eosin. Selected sections of gill. were stained also by the periodic acid Schiff reaction, the method of Gram and by Grocotts, Warthin-Starry, Feulgen, Giemsa and Ziehl Neelsen methods. Longitudinal sections of the second holobranch of each fish were prepared and histological descriptions were based on sections midway along the length of the primary lamellae. Lesions in gills are referred to as generalised when all secondary lamellae on all primary lamellae were affected, as locally extensive when large regions of secondary lamellae were affected but other regions on the same primary lamellus were normal, as multifocal when multiple small regions of secondary lamellae were affected and as focal when a single area of secondary lamellae was affected

Direct microscopic examination for bacteria, fungi, protozoa and metazoa. Gills from affected fish from selected collections in New South Wales and Western Australia were placed in a drop of saline and examined 
for the presence of filamentous bacteria, fungi, protozoa and metazoa at 10 and 100 times magnification using transmitted light. In addition, parasitological examination was conducted on whole-body scrapings and gills.

Electron microscopy. Gills were freeze dried without cleaning off the adhering debris, mounted on stubs, coated with gold-palladium and examined using a Philips XL20 scanning electron microscope. Gills from moribund New Zealand pilchards were excised, cut into $1 \mathrm{~mm}^{3}$ pieces, fixed for 1 to $2 \mathrm{~h}$ in $2.5 \%$ glutaraldehyde in $0.22 \mu \mathrm{m}$ filtered seawater (FSW), washed twice in FSW, post-fixed in 1\% osmium tetroxide for $1 \mathrm{~h}$, dehydrated through graded ethanol solutions, embedded in Araldite, sectioned, stained with 5\% uranyl acetate for $10 \mathrm{~min}$ and $5 \%$ lead citrate for 5 to 6 min, and examined on a Philips 420ST electron microscope. Gills and internal organs from Australian pilchards were prepared as described by Hyatt et al. (1997).

Bacterial culture. Gills were cultured on blood agar, MacConkey agar, marine agar, cytophaga agar and thiosulphate citrate bile salt sucrose medium. Kidney and spleen were cultured on marine agar and blood agar using standard techniques.

\section{RESULTS}

\section{Occurrence and spread of disease}

The mortality commenced in the vicinity of Anxious Bay, South Australia, in March 1995 and spread both west and east covering more than $2500 \mathrm{~km}$ in each direction over 3 mo (Fig. 1.). A plot of the elapsed time of the mortality front by its distance showed that the rate of spread to the west was slower than that to the east (Fig. 2) so the directional data were analysed separately. In both directions the Spearman rank correlation between elapsed time and distance was significant (to the east, $r=0.922, n=41$; to the west, $r=0.940$, $\mathrm{n}=22$ ). Linear regression was attempted, but the patterns of the residuals were unacceptable. To the east, variance decreased with distance from the origin, while to the west the pattern in the residuals was cyclic. Therefore, to estimate the rate of spread of the disease, distance was divided by elapsed time for each site. Examination of plots of these rates with distance as the independent variable showed that to the east the pattern changed after 26 April (at the western approaches to Bass Strait) from a median $12.1 \mathrm{~km} \mathrm{~d}^{-1}$ (range 1.3 to $21.2 \mathrm{~km} \mathrm{~d}^{-1}$, skew -0.04) to a median $32.4 \mathrm{~km} \mathrm{~d}^{-1}$ (range 8.0 to $36.2 \mathrm{~km} \mathrm{~d}^{-1}$, skew -0.97 ) through Bass Strait and northwards up the coast to Queensland. To the west the rate, after removal of 3 data points in South Australian waters prior to 24 March which had rates of 68 to $275 \mathrm{~km} \mathrm{~d}^{-1}$, showed a median rate of $30.4 \mathrm{~km} \mathrm{~d}^{-1}$ (range 3.3 to $43.2 \mathrm{~km} \mathrm{~d}^{-1}$, skew -1.36 ). The rate of spread to the west was against the eastward current of the Southern Ocean across the south of Australia and against the southward flowing warm Leeuwin Current which converges with the Southern Ocean waters (Fig. 1). Spread to the east was unaffected by the generally eastward movement of water to Tasmania and was not apparently affected by

Fig. 1. Occurrence and spread of the mortality front in pilchards in Australian waters. Dutes are those for the first observed mortality at each location. Sites of specimen collection and other sites named in the text are shown
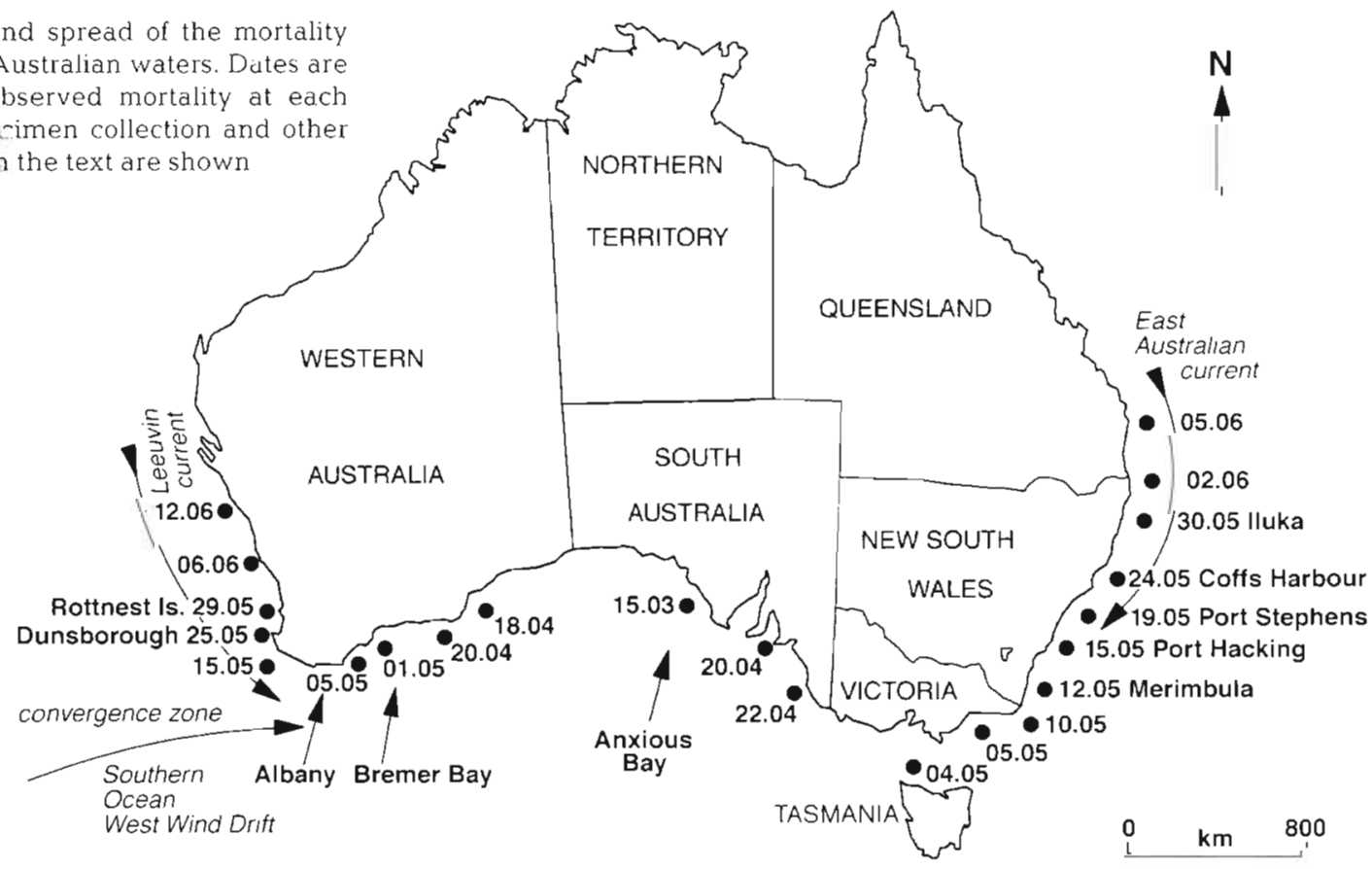


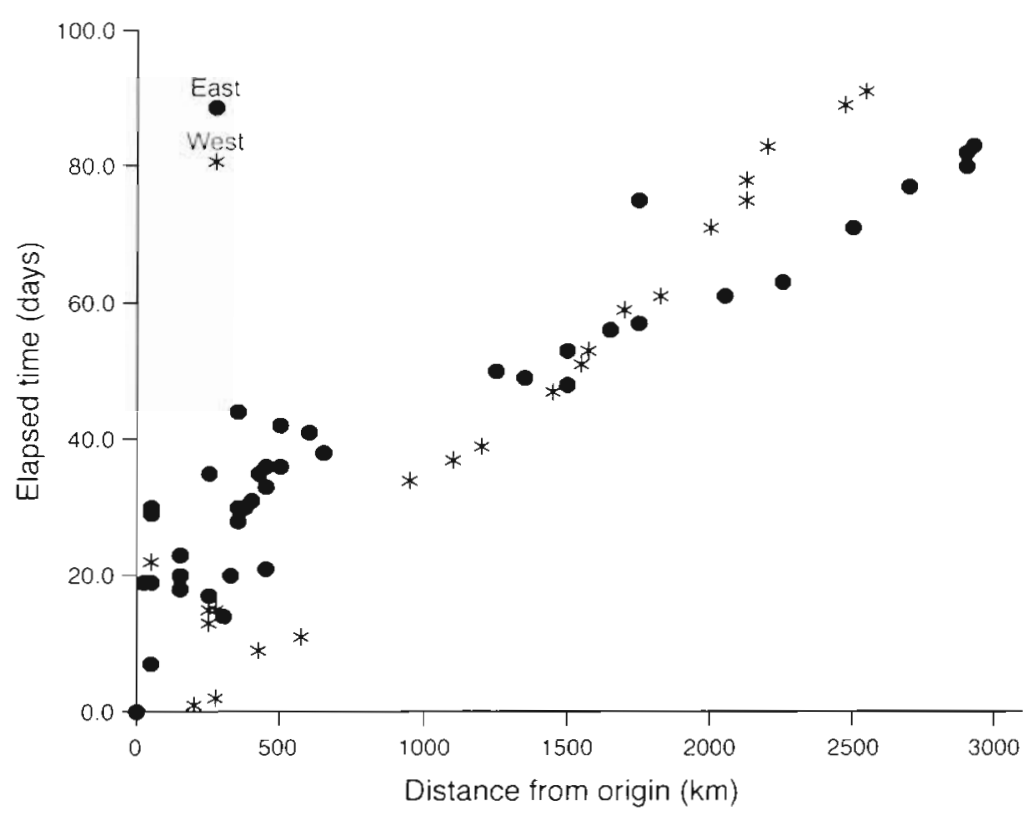

Fig. 2. Elapsed time of the mortality front in relation to distance from its origin in South Australian waters

the convergence zone between the warm East Australian Current flowing down the Queensland and New South Wales coast and the southern cold water (Fig. 1). The spread of the disease was not impeded by storm events; there were 3 during its progress through Western Australian waters, and one prolonged storm event during the spread in New South Wales waters.

In New Zealand, large-scale mortalities were noted first in Hauraki Gulf and the Firth of Thames on the east coast of the North Island in June 1995 and spread north through the Bay of Islands, rounding the tip of the North Island to reach Ninety Mile Beach by midJuly (Fig. 3). There were no reports of mortalities in central and southern waters of the North Island over this period or later. In August another mortality event commenced off the northwest tip of the South Island and spread east, reaching Wellington Harbour in midSeptember (Fig. 3).

The eventual distribution of the disease was discontinuous but observations were also discontinuous. Mortality was noted for only a few days at each location, consistent with an advancing disease front. Apparently healthy schools of pilchards were noted offshore from affected schools in western Australian, New South Wales and New Zealand waters and normal catches were recorded in each area within days of the mortality front passing. The exceptions were embayments such as Wellington Harbour where pilchards were rarely sighted in the weeks after the mortality event. Pilchards were the only species affected in Australia and in New Zealand.

\section{Clinical signs}

Adult pilchards of both sexes were affected (Table 1) and based on weightfor-age data (Fletcher 1990) these fish were at least 2 or 3 yr old. Affected fish along the south coast of Western Australia (Bremer Bay, Albany) were $\geq 4$ yr old, 2 and 3 yr old fish being absent from the fishery, while the affected fish off the west coast of Western Australia were $\geq 2$ yr old (R. Fletcher pers. comm.). The mortalities occurred at different times in relation to spawning ffrom several months before to several months after, depending on location) suggesting a lack of relation to the reproductive cycle. In Western Australia, juvenile fish were seen schooling under and in the vicinity of schools of affected adults but were not themselves clinically affected.

Observers on boats noted that affected pilchards comprised a small proportion of the pilchards in schools that appeared otherwise to behave normally. However, many more dead fish appeared when the schools were chased. Dead fish floated to the surface to form large rafts while apparently unaffected fish schooled 0.5 to $3 \mathrm{~m}$ below. One observer in New Zealand reported that affected fish left the school, ceased swimming, turned onto their sides, resumed swimming sluggishly and then died in extremis within a few minutes. When disturbed, moribund fish jumped erratically from the water. Underwater observations in New Zealand

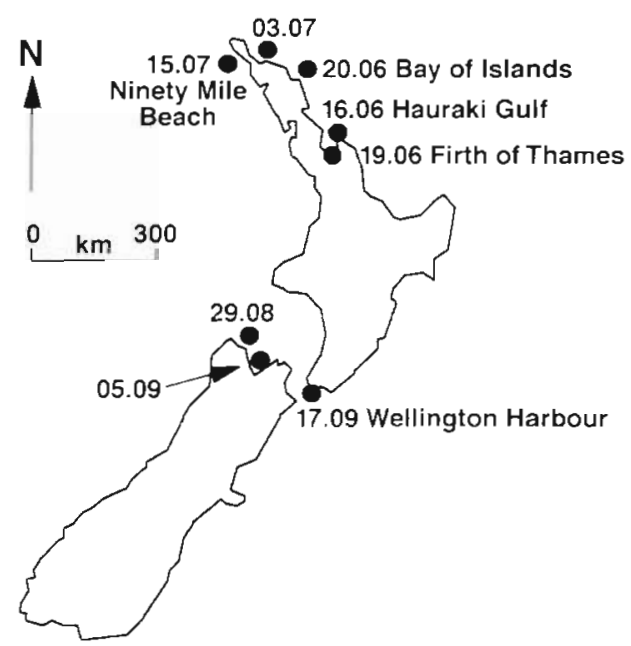

Fig. 3. Occurrence and spread of the mortality front in pilchards in New Zealand waters. Dates are those for the first abserved mortality at each location. Sites of specimen collection and other sites named in the text are shown 


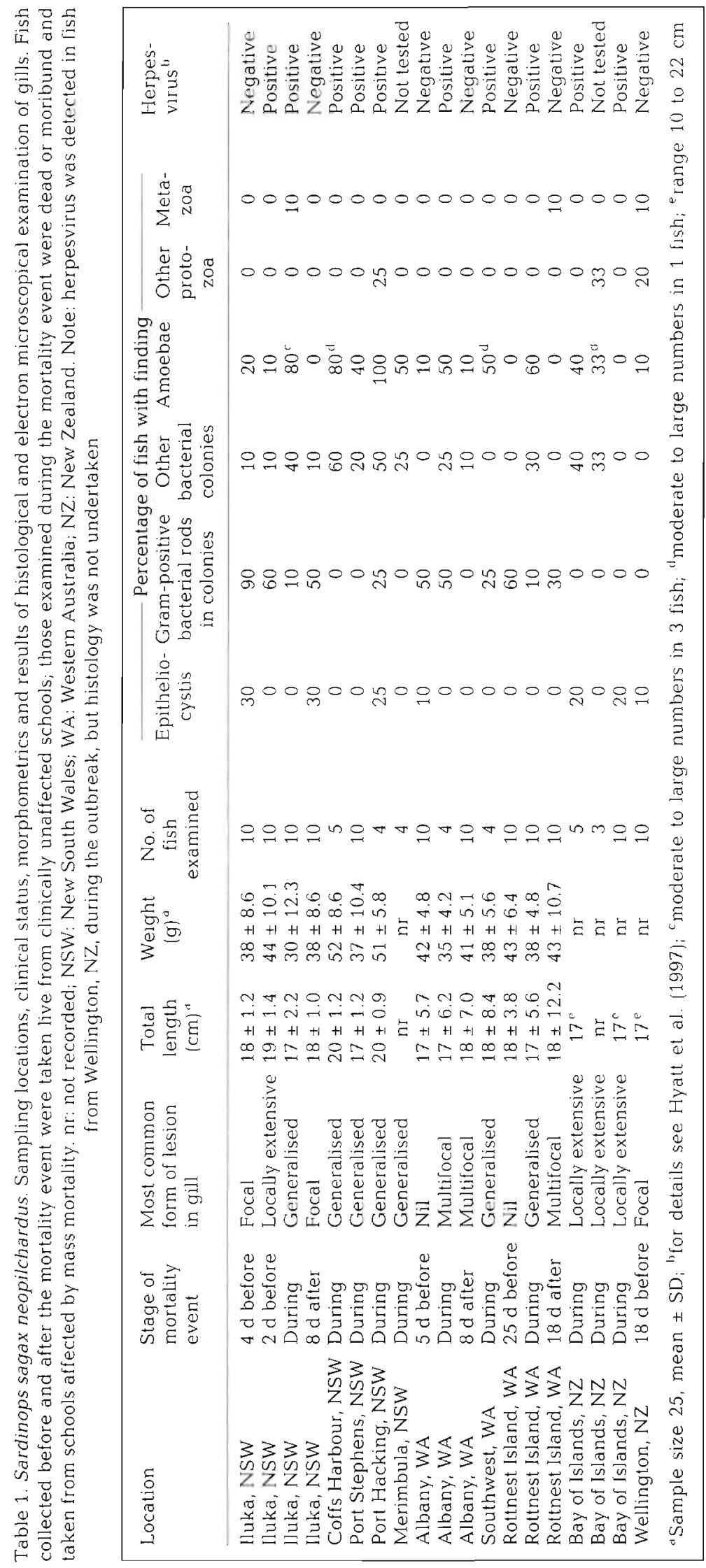

revealed that affected schools contained individuals of varying size and that only the larger fish were dying. Death occurred within minutes of the first signs of distress while the remaining fish were schooling normally. The rate of mortality increased suddenly when the school was startled; flashing behaviour commenced within $15 \mathrm{~s}$ and death within 3 to $5 \mathrm{~min}$. Many dead pilchards had sunk to the bottom. Accurate estimates of the mortality rate were not made at any location, although 10\% was suggested in Western Australia ( $R$. Fletcher pers. comm.).

\section{Gross pathology and direct microscopic examinations}

Apart from traumatic lesions associated with netting, there were few gross abnormalities and most fish were in good bodily condition. Some had died with the mouth open and the operculae abducted. Vascular congestion around the eyes was observed in some moribund and dead pilchards in New Zealand. The gills of freshly collected affected fish were dark red to dark brown while those of unaffected pilchards were bright red. It was uncertain whether this difference was related to the time since death, since in general the affected fish were removed dead from the water while the normal fish were removed alive. However, blood collected from live affected pilchards that were caught after being startled by SCUBA divers was noticeably darker than blood of healthy pilchards caught by rod and line. Mucus was not apparent on the gills. One affected fish had pale streaks in the myocardium later found to be due to microsporidian cysts. The degree of fill of the gastrointestinal tract varied between schools without apparent relationship to the presence of disease. The spleen varied from a pale brown structure $10 \mathrm{~mm}$ (length) $\times$ $2 \mathrm{~mm}$ (maximum wiath) to a dark red to black structure $20 \mathrm{~mm} \times 5 \mathrm{~mm}$ but size did not correlate with disease status.

No filamentous bacteria, fungi, protozoa or metazoa were observed in direct mounts of gills of affected fish from New South Wales or Western Australia. No parasites were observed in whole-body 
scrapings of 10 fish caught at Iluka $4 \mathrm{~d}$ before the mortality event, while small numbers of gliding bacteria were seen in gill smears of 2 of 15 fish from this site. Gill scrapings and smears from 5 freshly dead fish collected off Rottnest Island, Western Australia were specifically examined for amoebae but none were found.

\section{Histopathology of tissues other than gills}

Liver, kidney, spleen, brain, heart, pancreas, gastrointestinal tract, gonad, skin and skeletal muscle were examined from pilchards that were collected from Iluka, New South Wales, $4 \mathrm{~d}$ before the mortality event $(n=5), 2 \mathrm{~d}$ before the event $(n=5)$, during the event $(n=5)$ and $8 d$ after the event $(n=5)$ and from affected fish from Port Hacking $(n=4)$ and Port Stephens $(n=10)$. There were occasional insignificant abnormalities in a range of tissues from occasional fish from each group, including microsporidian cysts in myocardium and skeletal muscle unassociated with inflammation, metazoan parasites in the gastrointestinal tract and peritoneal cavity, intestinal coccidia and scattered inflammatory foci in various organs. The exocrine pancreas was autolytic or scant in many fish. The large spleens were engorged with erythrocytes, while small spleens contained few erythrocytes. There was mild to marked. vacuolar change of the liver in most fish and mild to severe autolysis of the gastrointestinal tract. There were no significant findings in most affected fish from Western Australian waters although a coccidian, Goussia sp., was found in the liver of some. The oocyte diameter was approximately $20 \mu \mathrm{m}$ while the spore size was $9-10 \times 6 \mu \mathrm{m}$ with residuum, which is consistent with $G$. clupearum (Levine 1983). Kudoa thyrsites was occasionally seen in the musculature of pilchards from Western Australia as previously recorded by Langdon (1991)

\section{Histopathology of gills}

Histology of unaffected fish. Secondary lamellae were of uniform length, straight and evenly distributed along the primary lamellae. Secondary lamellae were covered by a single thin layer of epithelium that was closely apposed to the pillar cells. The epithelial cell nuclei were flattened, while the cytoplasmic processes were indistinct (Fig. 4). Chloride cells were abundant on some primary lamellae but were absent from others; this was determined by the plane of section. Where present, chloride cells were restricted to the bases of

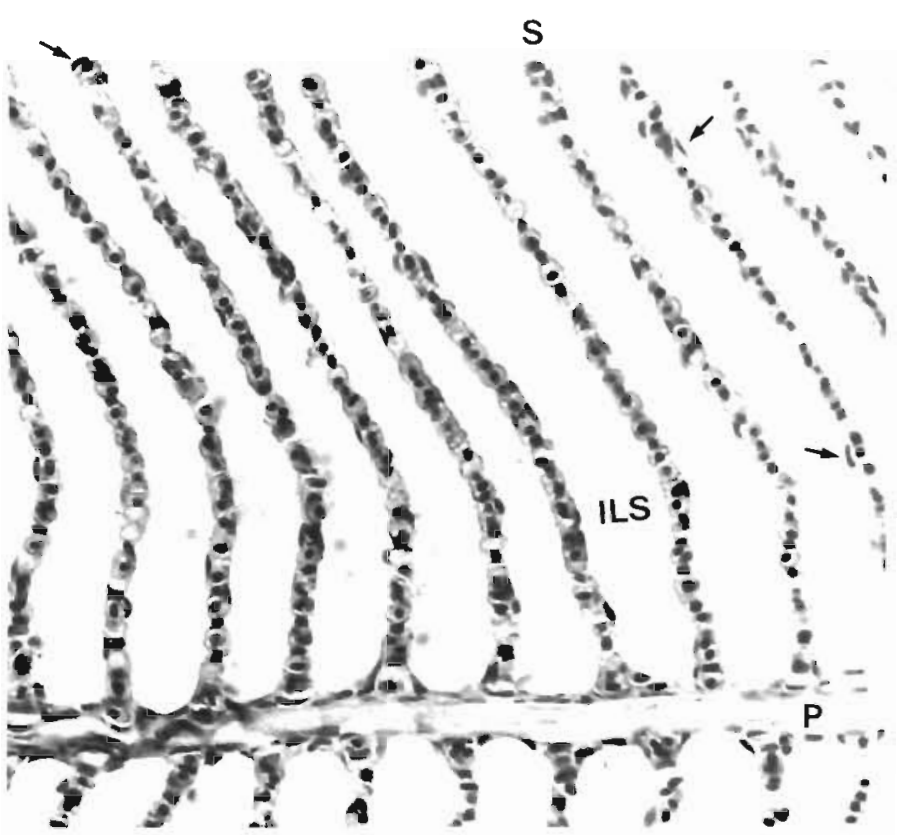

Fig. 4. Sardinops sagax neopilchardus. Normal pilchard gill, Iluka, New South Wales. In this section the primary lamellus is devoid of chloride cells. P: Primary lamellus; S: secondary lamellae; ILS: interlamellar space. Note flattened epithelial cell nuclei (arrows). $\times 450$

the interlamellar spaces and were found singly, in pairs or groups along the entire length of the primary lamellus, either within or below the epithelium. Mucous cells were rarely present in the epithelium of the secondary lamellae but they did occur on the tips of the primary lamellae in some fish.

Iluka, New South Wales -4 d before the mortality event. There were single or multiple, small foci of subepithelial proteinaceous oedema along the secondary lamellae in 4 of 10 fish. A separate focus of branchitis in one of these was characterised also by proliferation of chloride cells and mild lymphocytic infiltration (Fig. 5). There was a single small focus of mild epithelial hyperplasia in each of 2 fish.

Iluka, New South Wales $-2 \mathrm{~d}$ before the mortality event. There were multifocal to locally extensive inflammatory lesions aftecting some primary lamellae in 10 of 10 fish. In 8 fish there was also focal ( 4 fish) or multifocal (4 fish) epithelial hyperplasia; in the remaining 2 fish there was multifocal to locally extensive epithelial hypertrophy. The secondary lamellae were normally aligned or were folded, mildly distorted and apparently shortened. Inflammation was characterised by subepithelial and luminal exudates of small to moderate numbers of eosinophilic granulocytes, chloride cells, lymphocytes and occasional neutrophils (Figs. 6 \& 7) while macrophages were also present in $2 \mathrm{fish}$. In affected areas the epithelial cell 


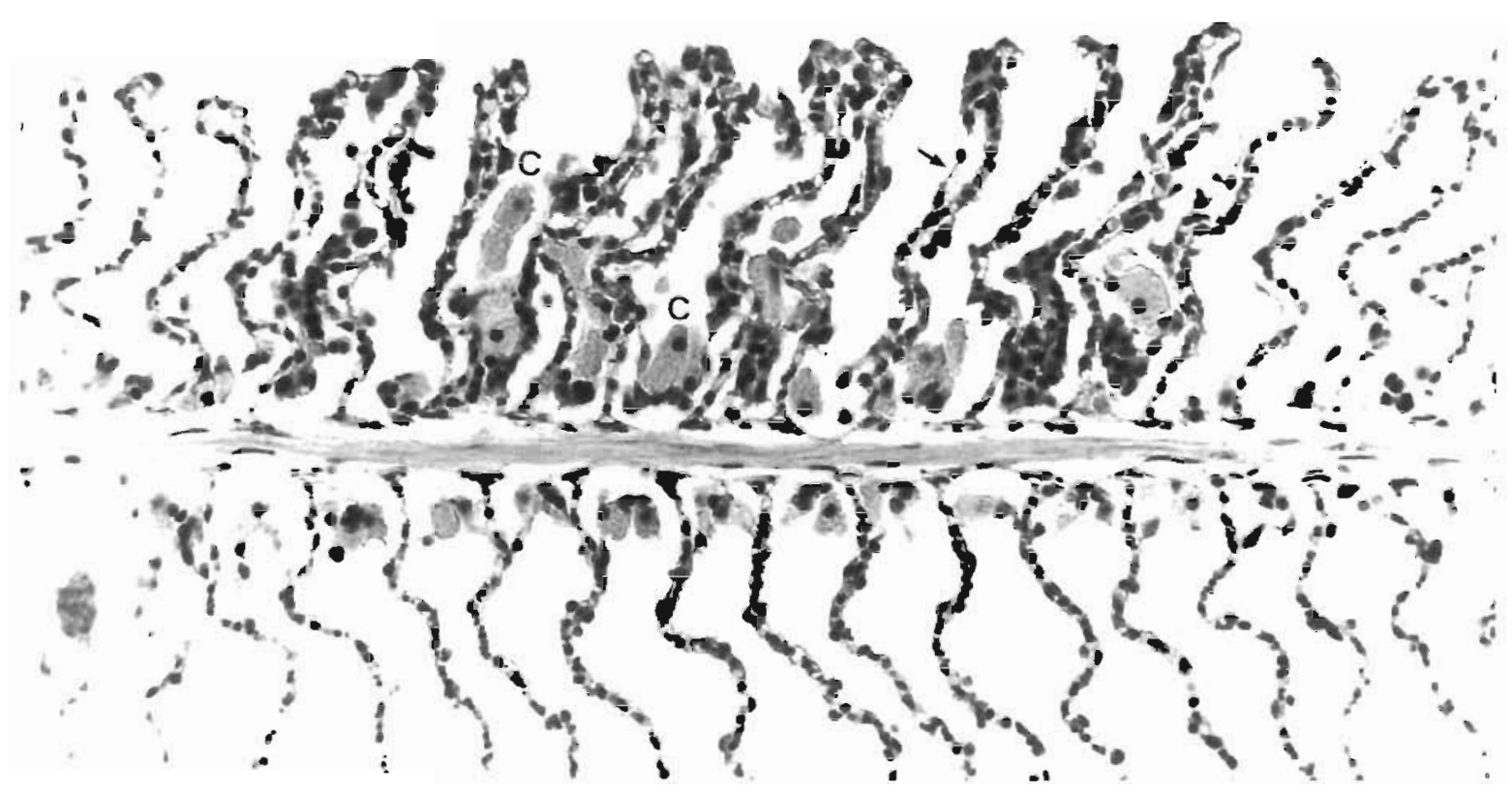

Fig. 5. Sardinops sagax neopilchardus. Fish collected (live) $4 \mathrm{~d}$ before the mortality event at Iluka, New South Wales. There is focal branchitis with subepithelial proteinaceous oedema (arrow), chloride cell proliferation (C), a mild lymphocytic infiltrate and early epithelial hypertrophy, $\times 450$

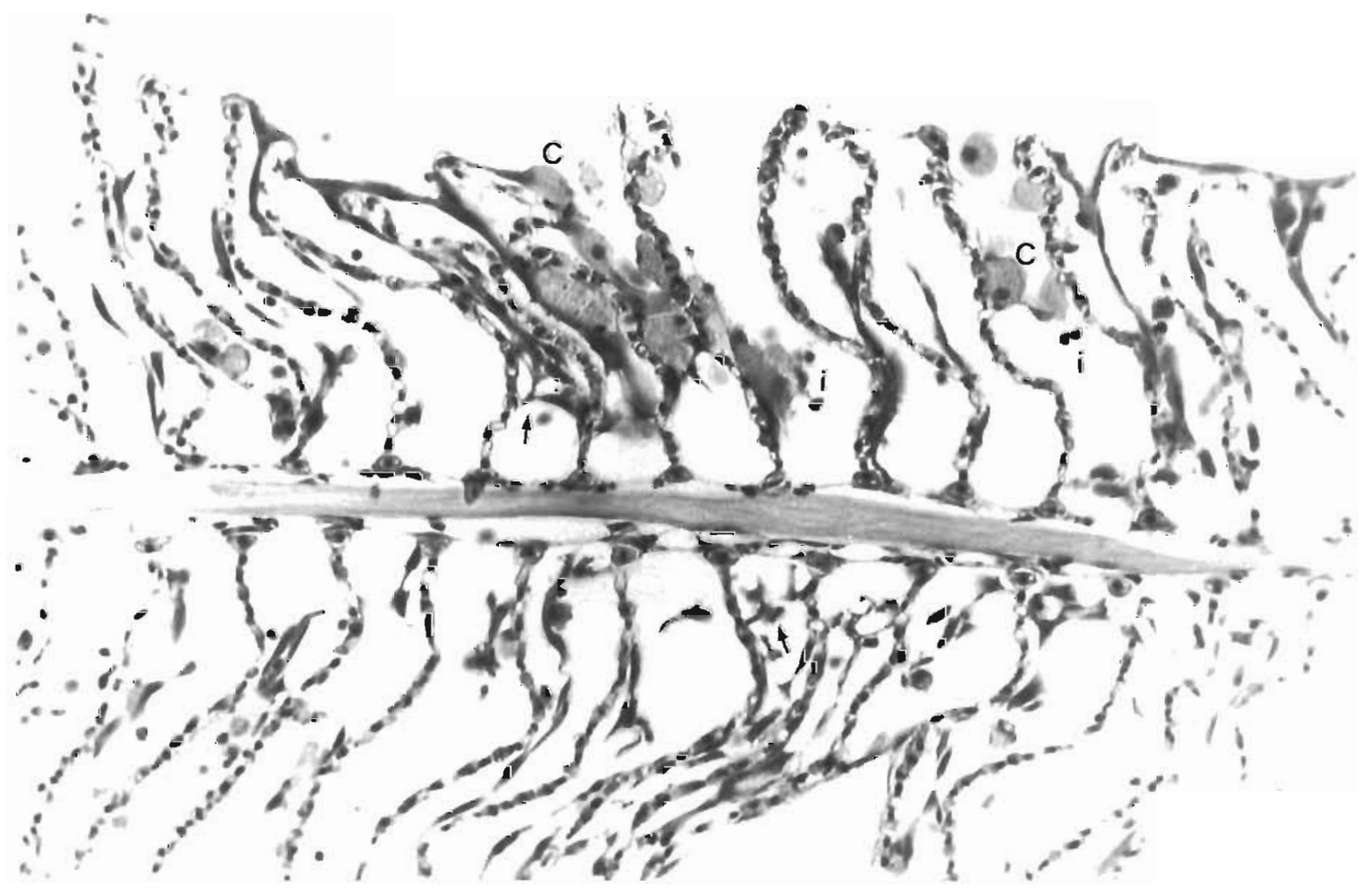

Fig. 6. Sardinops sagax neopilchardus. Fish collected (live) $2 \mathrm{~d}$ before the mortality event at Iluka, New South Wales. Part of primary lamellus with locally extensive branchitis. There is proliferation of chloride cells $(\mathrm{C})$, mild infiltration of mixed inflammatory cells (i) and epithelial cell elevation and hypertrophy forming cytoplasmic bridges (arrows) between adjacent secondary lamellae. $\times 450$ 


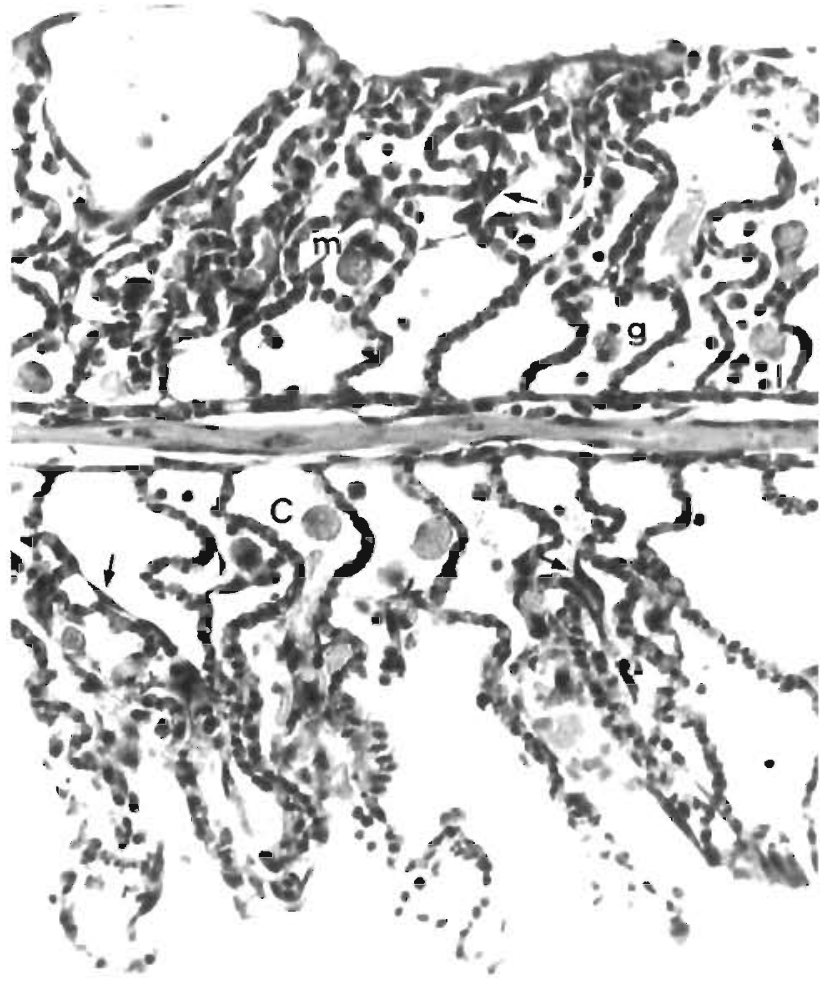

Fig. 7. Sardinops sagax neopilchardus. Fish collected (live) $2 \mathrm{~d}$ before the mortality event at lluka, New South Wales. Part of primary lamellus with multifocal branchitis. There is a mixed inflammatory cell exudate in distended subepithelial and interlamellar spaces with epithelial hypertrophy (arrows). l: lymphocytes; m: macrophage; g: eosinophilic granulocyte, C: chloride cell. $\times 450$ nuclei were elevated and enlarged and their cytoplasmic processes were abundant, intensely basophilic and extended to bridge adjacent secondary lamellae to form intraepithelial spaces (Fig 7, see also Fig. 14). In 2 fish the hyperplastic response resulted in the formation of epithelial islands in the interlamellar spaces. An inflammatory exudate was often present in the subepithelial space adjacent to focal proliferative lesions

Iluka, New South Wales-during the mortality event. There was moderate to severe, locally extensive to generalised inflammation, epithelial hypertrophy and epithelial hyperplasia in 10 of 10 fish (Fig. 8). Secondary lamellae were folded, distorted and apparently shortened. Islands of hyperplastic epithelium and cystic spaces containing inflammatory cells and cell debris were present in interlamellar spaces (Figs. 8 \& 9). In 7 fish the interlamellar spaces were filled by hyperplastic epithelium (Fig. 9). The epithelial cells were hypertrophic, deeply basophilic and detached segmentally from the basement membrane. The subepithelial space was empty or contained eosinophilic fibrillar and granular material and/or a mixed inflammatory cell exudate with small numbers of eosinophilic granulocytes, chloride cells, lymphocytes, occasional neutrophils, macrophages and cell debris. The exudate appeared to be less well-developed than in the samples collected before the mortality event. Autolysed free erythrocyte nuclei within the vessels of the secondary lamellae resembled viral inclusions in one fish (Fig 10); true viral inclusion bodies were not observed in any fish.

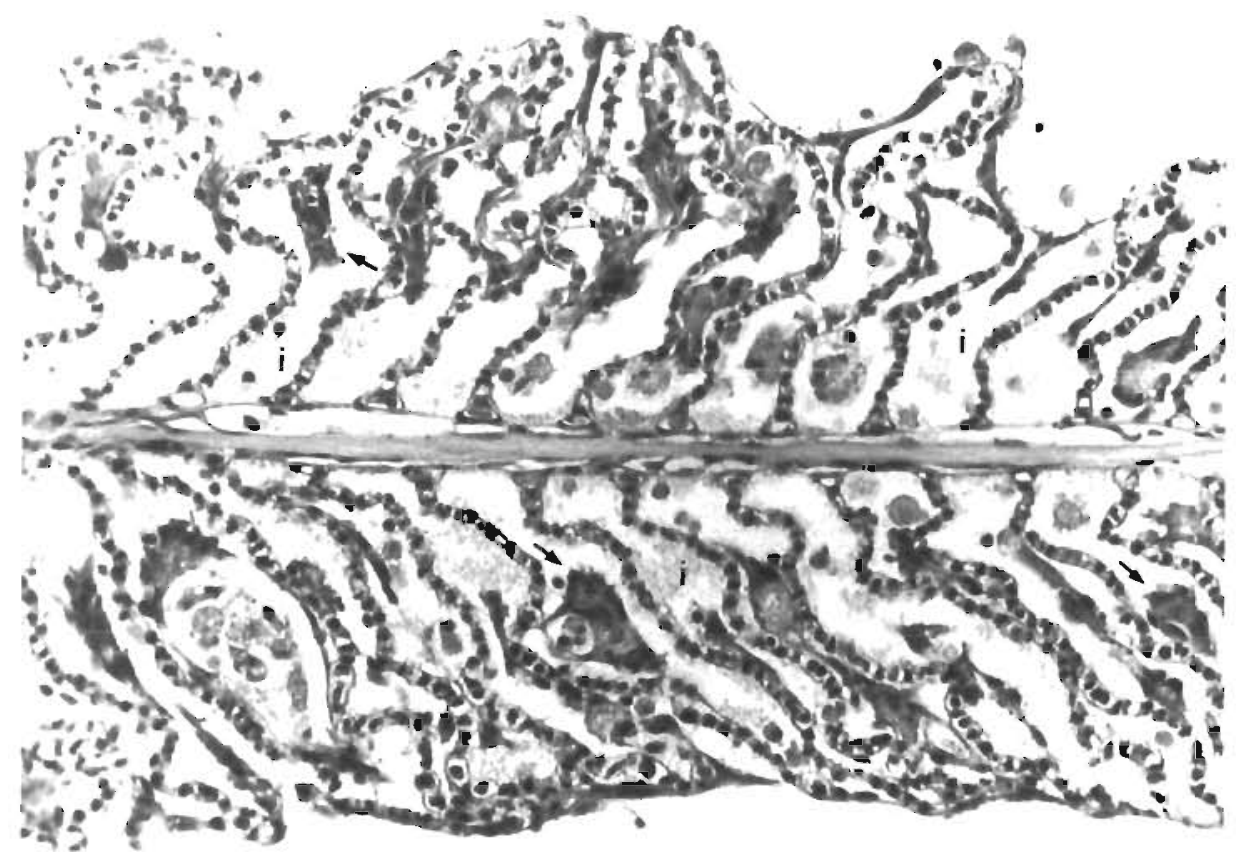

Fig. 8. Sardinops sagax neopilchardus. Fish collected (dead) during the mortality event at lluka, New South Wales. Part of primary lamellus with generalised branchitis and mild epithelial hyperplasia forming islands (arrow) and cystic spaces. Infiltrate with proteinaceous fluid and inflammatory cells (1). $\times 450$ 


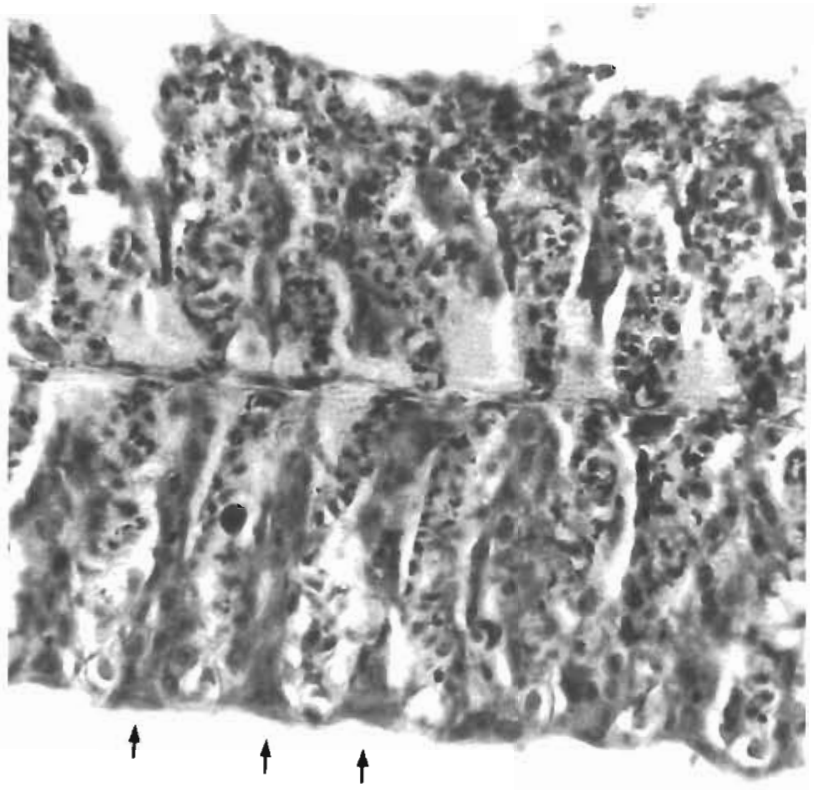

Fig. 9. Sardinops sagax neopilchardus. Fish collected (dead) during the mortality event at Iluka, New South Wales. Autolysed gill. Consolidation of interlamellar spaces with hyperplastic epithelium (arrows) $\times 450$

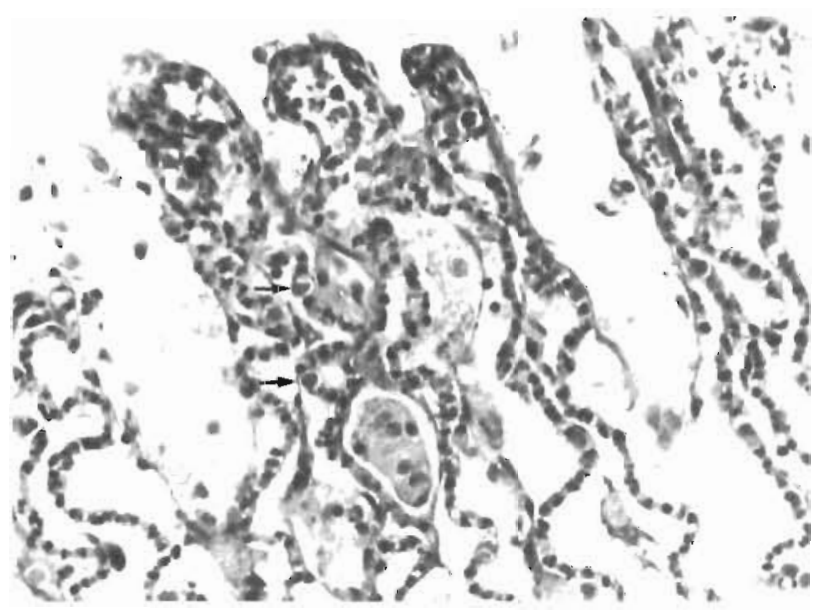

Fig. 10. Sardinops sagax neopilchardus. Fish collected (dead) during the mortality event at lluka, New South Wales. Autolysed gill with inflammation, epithelial hypertrophy and erythrocyte nuclei resembling viral inclusion bodies (arrows) $\times 500$

Iluka, New South Wales -8 d after the mortality event. There were no lesions in the gills of 6 of 10 fish. There was locally extensive acute branchitis in one fish; the subepithelial exudate consisted of eosinophilic granulocytes, chloride cells, lymphocytes and occasional neutrophils and there was early epithelial hypertrophy. In a second fish there was a single focus of epithelial hypertrophy and hyperplasia with a subepithelial exudate of eosinophilic granulocytes, lym- phocytes, chloride cells and occasional neutrophils and macrophages. This lesion spanned apposing secondary lamellae on adjacent primary lamellae. Adjacent secondary lamellae were united discontinuously along their length and at their tips by attenuated cytoplasmic projections of hypertrophic epithelial cells and 2 intraepithelial cystic spaces were present at the margin of the lesion. There were scattered, small, focal, lamellar lesions in 2 other fish. These consisted of fusion of 2 to 4 adjacent secondary lamellae with epithelial hypertrophy and hyperplasia but did not resemble the process described in fish before or during the mortality event.

Albany, Western Australia. There were no significant lesions in the gills of 10 of 10 fish collected $5 \mathrm{~d}$ before the mortality event. There were multiple foci of mild inflammation and epithelial hypertrophy in the gills of 2 of 4 apparently healthy fish which were netted from a school at the onset of the mortality event. The lesions resembled those in Fig. 5. Eight days after the mortality event there were focal to multifocal inflammatory lesions with epithelial hypertrophy in the gills of 3 of 10 apparently healthy fish.

Rottnest Island, Western Australia. There were no significant lesions in the gills of 10 of 10 fish collected $25 \mathrm{~d}$ before the mortality event. One day after the onset of the mortality event there was locally extensive to generalised inflammation and epithelial hyperplasia in the gills of 10 of 10 affected fish. The gill was consolidated by epithelium in 2 fish and there were widespread islands of hyperplastic epithelium in 4 fish. Chloride cells, lymphocytes and neutrophils were prominent in the inflammatory exudates while eosinophilic granulacytes were uncommon. Eighteen days after the mortality event there was multifocal to locally extensive inflammation in the gills of 3 of 10 apparently healthy fish. The cellular exudates consisted predominantly of chloride cells and lymphocytes.

Other locations. Findings in the gills of affected fish from other locations were similar to those described above and varied only in the degree of inflammation and hyperplasia. The epithelial hyperplasia in affected fish from New Zealand was less advanced than in most of the affected fish from Australia (Figs. 11 \& 12); generalised lesions were present in 4 of 18 affected fish from the Bay of Islands. Degranulating eosinophilic granulocytes were more abundant in the inflammatory exudates in some affected pilchards from New Zealand (Fig. 11) than in most of those from Australia.

Bacteria, protozoa and metazoa in gill sections. A range of microorganisms was observed in the gills of normal and affected pilchards and their prevalence is given in Table 1. With the exception of a few affected fish that had large numbers of amoebae (Table 1), none 


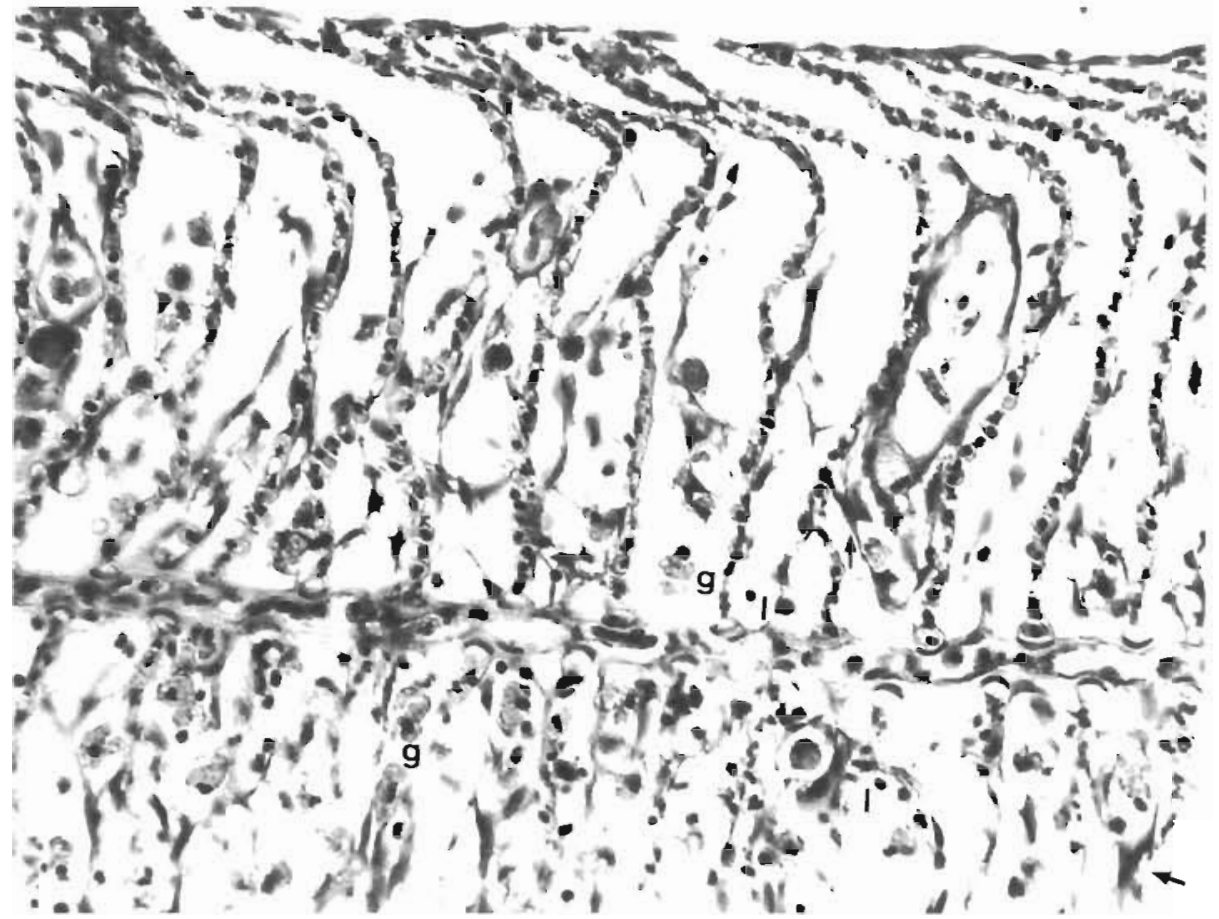

Fig. 11. Sardinops sagax neopilchardus. Fish collected (dead) during the mortality event at Bay of Islands, New Zealand. There is generalised branchitis, epithelial hypertrophy and mild epithelial hyperplasia (arrows) g: eosinophilic granulocytes; I: lymphocytes. $\times 500$

of these organisms were numerous. The amoebae appeared as round, crescentic to irregularly shaped pale, amphophilic organisms with a few cytoplasmic granules (Kent et al. 1988, Roubal et al. 1989) and were present on the superficial epithelium, on the epithelium of the interlamellar spaces and in intraepithelial cystic spaces. Epitheliocystis (Inglis et al. 1993) were present in the epithelium in very small numbers. Bacteria were not seen on gills of the majority of affected fish but a few small colonies of robust Gram-positive coccobacilli were found in the interlamellar spaces of fish regardless of disease status. Small colonies of Gram-negative, fine, short to filamentous rods were sometimes found associated with cell debris in intra-

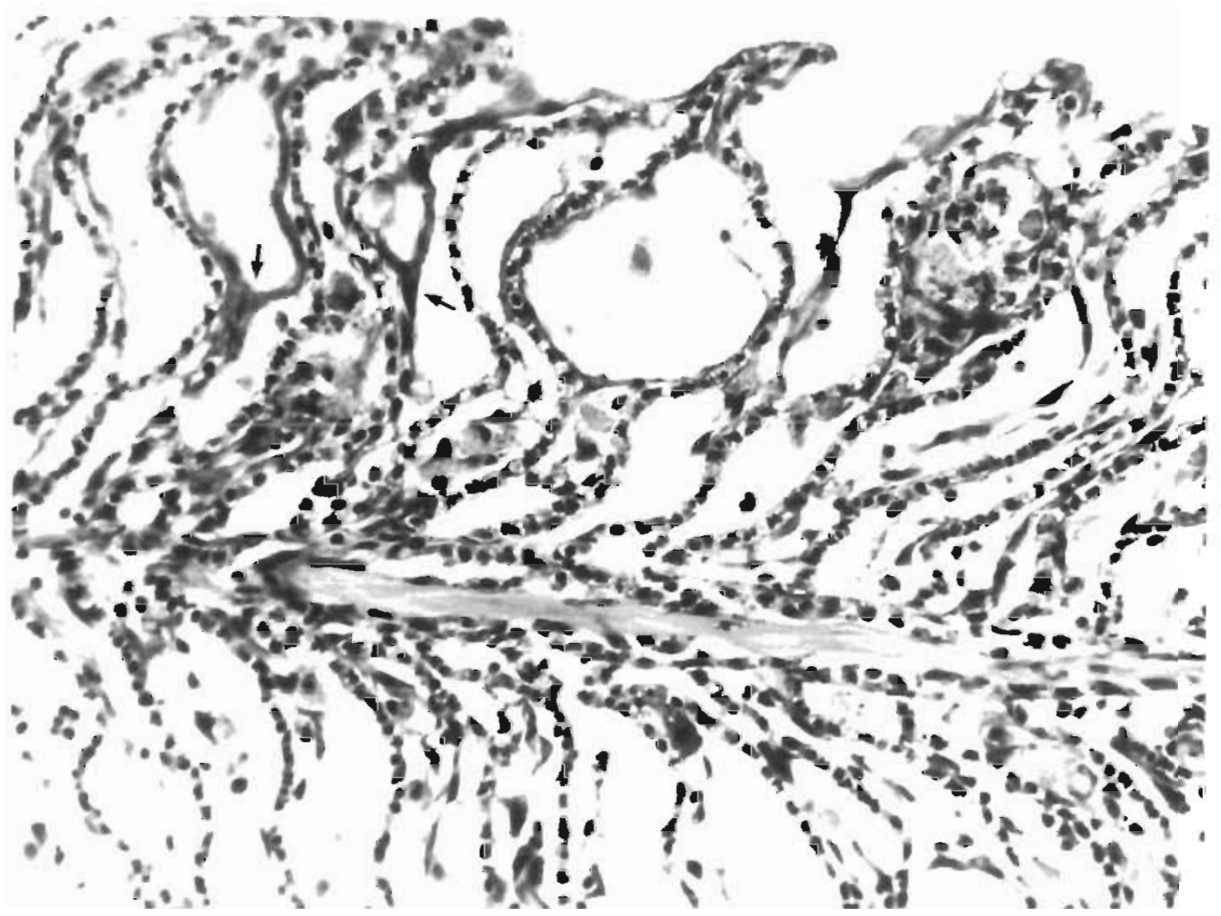

Fig. 12. Sardinops sagax neopilchardus. Fish collected (dead) during the mortality event at Bay of Islands, New Zealand. There is generalised branchitis, epithelial hypertrophy and mild hyperplasia (arrows) $\times 450$ 
epithelial cystic spaces and on the epithelial surface of affected fish. These bacteria were never numerous and were obvious only in the most severely affected gills, for example those from Port Hacking and Coffs Harbour Single metazoa were found on the gills of 3 fish.

\section{Electron microscopy}

In scanning electron micrographs there were no adhering algae or algal spines (Yang \& Albright 1992) or evidence of mechanical damage in the gills of 2 moribund and 2 dead fish from Bremer Bay, Western Australia. A small copepod was found embedded in the base of the secondary lamellae of one fish; this was confirmed histologically but whole specimens for taxonomic identification were not obtained. There are no records of copepods on Australasian pilchards.

In transmission electron micrographs granulocytes containing large granules with a condensed or crystalline plate or rod were observed in the subepithelial space and moving through the epithelium to the interlamellar space (Fig. 13). Cytoplasmic processes from hypertrophic epithelial cells contacted those from adjacent secondary lamellae and were joined by desmosomes (Fig. 14). The cytoplasm of these cells was rich in ribosomes. Herpesvirus particles were observed in the epithelial cells of affected fish from the locations shown in Table 1 and from Wellington Harbour, New Zealand, during the outbreak; additional ultrastructual findings and viral prevalence data are given in Hyatt et al. (1997) Viral particles were not observed in kidney or spleen from 4 affected fish from Iluka, New South Wales nor from pancreas from affected fish from Port Hacking, New South Wales.

\section{Bacterial culture}

No significant bacterial growth was obtained from gills of 5 fish collected at lluka 4 d before the mortality event nor from kidney and/or spleen of 6 fish collected $4 \mathrm{~d}$ prior to the mortality event in Western Australia. There were no significant bacterial isolates from kidney and/or spleen of 13 freshly dead fish collected during the mortality event at Albany and Rottnest Island, Western Australia.

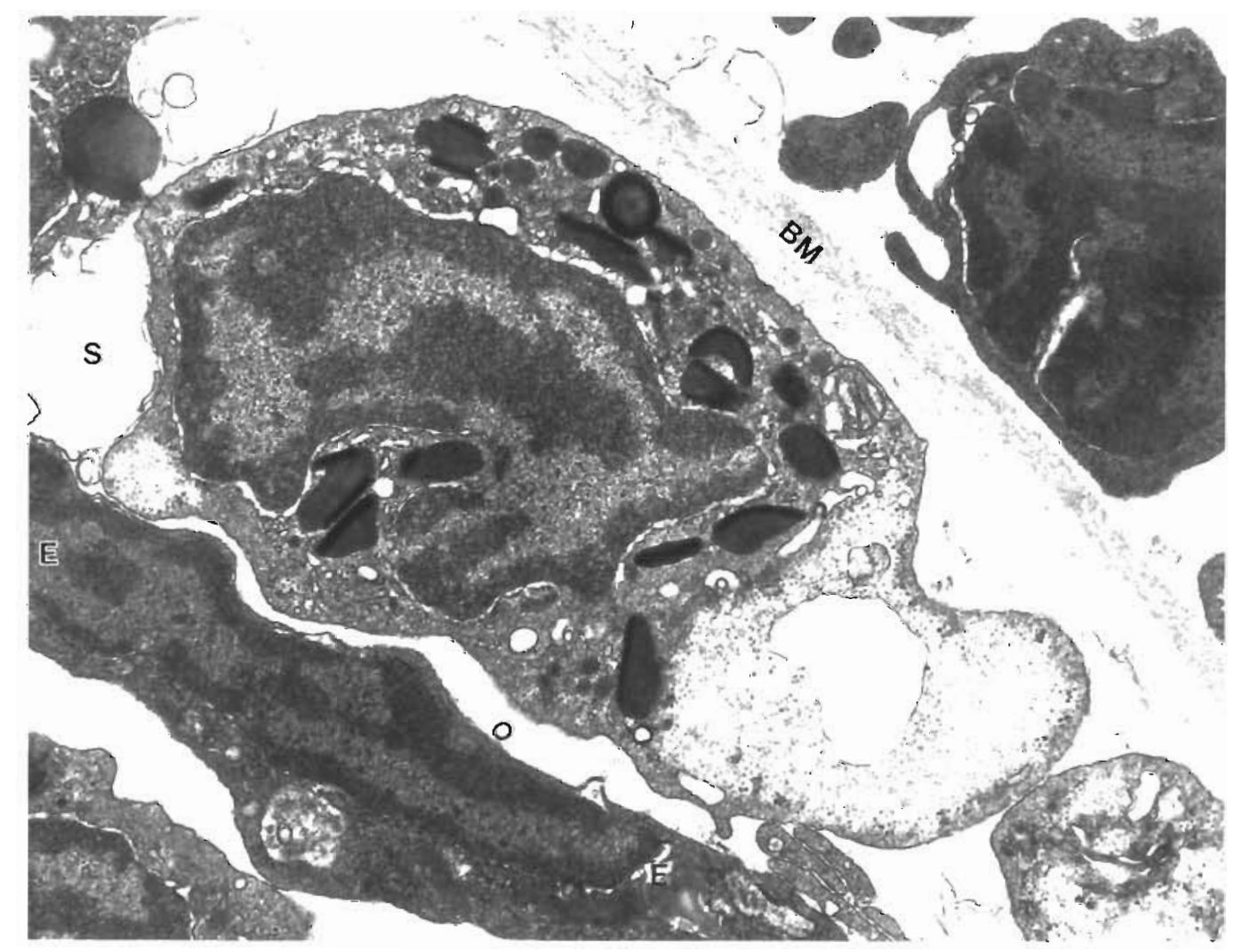

Fig. 13. Sardinops sagax neopilchardus. Transmission electron micrograph, fish collected at Bay of Islands, New Zealand. Eosinophilic granulocyte in the subepithelial space. It contains dense granules, each with a peripheral condensation. BM: basement membrane; S: subepithelial space; E: epithelial cell. $\times 19500$ 


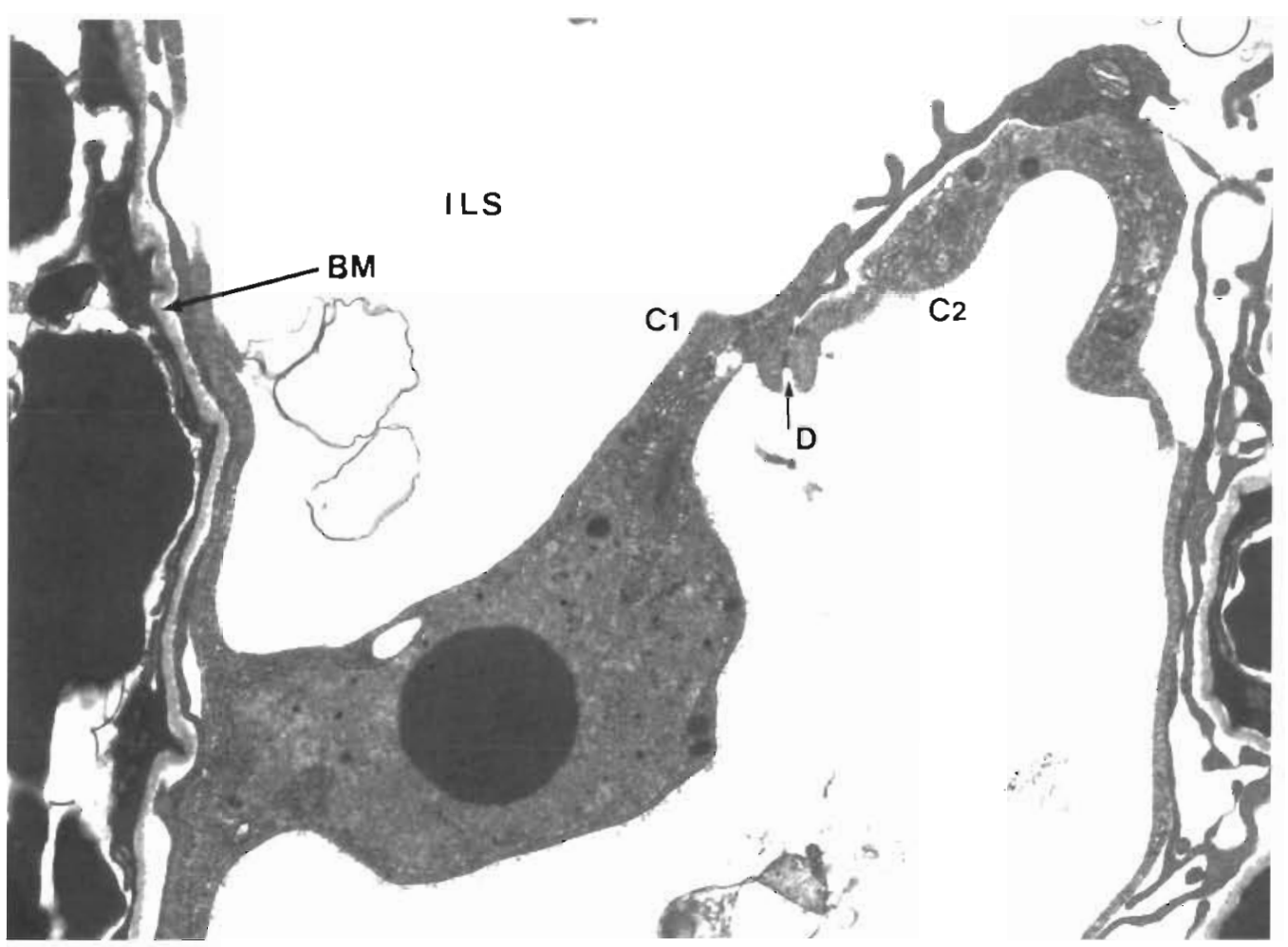

Fig. 14. Sardinops sagax neopilchardus. Transmission electron micrograph, fish collected at Bay of Islands, New Zealand. Hypertrophic epithelial cell. infected with herpesvirus (see Hyatt et al. 1997). A cytoplasmic process (C1) crosses the interlamellar space (ILS) to join by desmosomes (D) to the cytoplasmic process (C2) from another epithelial cell. BM: basement membrane. $\times 12000$

\section{Blood gas analysis}

Affected pilchards had a significant reduction in the partial pressure of oxygen and percent oxygen saturation in blood compared to normal pilchards (Table 2). In addition affected pilchards had significant reductions in blood $\mathrm{pH}$ and bicarbonate concentration and a significant increase in the partial pressure of carbon dioxide, suggesting both respiratory and metabolic acidosis

Table 2. Sardinops sagax neopulchardus. Blood gas analysis of normal and affected pilchards from Wellington Harbour, New Zealand. Blood was collected from 8 normal pilchards and 12 affected pulchards and was analysed after pooling into 4 and 6 samples, respectively. Data are means \pm SD

\begin{tabular}{|lrrr|}
\hline Parameter & Normal & Affected & $\mathrm{p}$ \\
\hline $\mathrm{pH}$ & $7.3 \pm 0.18$ & $6.7 \pm 0.09$ & 0.0048 \\
$\mathrm{pCO}_{2} \mathrm{mmHg}$ & $25.3 \pm 7.28$ & $59.1 \pm 8.79$ & 0.0003 \\
$\mathrm{pO}_{2} \mathrm{mmHg}$ & $23.8 \pm 4.73$ & $16.05 \pm 6.66$ & 0.0700 \\
$\mathrm{HCO}_{3}^{-} \mathrm{mmol} \mathrm{I}^{-1}$ & $10.9 \pm 1.48$ & $6.90 \pm 0.76$ & 0.0077 \\
$\mathrm{O}_{2}$ saturation \% & $31 \pm 12.2$ & $6 \pm 4.5$ & 0.0290 \\
\hline
\end{tabular}

\section{DISCUSSION}

Clupeoids are among the most numerous and readily observable of the marine fishes but little is known of their diseases. Stranding induced by predators and weather conditions, physicochemical factors and Ichthyophonus infection have been responsible for mass mortalities of clupeoids in North America (Sindermann 1990). However, the cause of many mortalities was unknown, for example when $1000 \mathrm{t}$ of Pacific herring Clupea harengus pallasi died in British Columbia in 1949. More recently in Alaska, 15 to $43 \%$ of spawning Pacific herring had external ulcers or haemorrhages associated with viral haemorrhagic septicemia virus (Meyers et al. 1994). This virus might also have been responsible for mass mortalities associated with subcutaneous haemorrhage in Pacific sardines Sardinops caeruled and Pacific herring in 1941-1942 in British Columbia (Sindermann 1990).

Diseases of pilchards are poorly documented, although several parasites have been recorded. We are aware of only one other pilchard kill in Australia. Copas (1982) reported that thousands of 15 to $25 \mathrm{~cm}$ pilchards were washed ashore in northern Tasmania and had signs 'consistent with crushing' The localised 
nature of this event and the dramatic gross pathology clearly distinguish it from the present epizootic. In New Zealand, isolated pilchard kills are relatively common. Jones \& Rhodes (1994) reported an algal bloom that killed about $500 \mathrm{~kg}$ of pilchards in a small lagoon in Wellington Harbour. There were other fish kills in New Zealand in 1994 and 1995 that were thought to involve pilchards but these occurred inshore or in embayments, did not spread and the species involved were not confirmed. There are earlier, mostly anecdotal accounts of pilchard deaths in New Zealand (Graham 1954). These occurred in 1900-1902, 1921 and 1934 when quantities of fish were washed ashore and processed for human consumption. On some occasions the pilchards had been 'thrown up by the sea' or chased ashore by predatory fish.

Thus to our knowledge the event described in this report is the only extensive and progressive epizootic to have affected the Australasian pilchard. A longitudinal study was undertaken to define the condition and its aetiopathogenesis

The disease observed in fish from New South Wales and Western Australia had a logical progression from mild acute focal to severe subacute generalised branchitis. A few residual cases were present after the main disease front had passed but there was no evidence of resolution of the severe lesions observed during the mortality event, suggesting a high case fatality rate. The primary lesion was inflammatory; there was leakage of protein from pillar capillaries and exudation of inflammatory cells into the subepithelial space. Chloride cells detached from their basal location, moved into subepithelial spaces along the secondary lamellae and may have proliferated. Eosinophilic granulocytes were common in the exudates and their degranulation might have played a role in the pathogenesis of the lesions by inducing vascular leakage. Neutrophils, lymphocytes and a few active macrophages were also present. Further studies to classify the granulocytes are in progress. Inflammation subsided as epithelial hypertrophy and hyperplasia supervened; secondary lamellae became distorted. The epithelial cells enlarged and extended cytoplasmic processes to join to those from adjacent secondary lamellae (Fig. 14). The nuclear to cytoplasmic ratio increased as the hyperplastic response matured. Islands of epithelium appeared in the interlamellar spaces, eventually obliterating them. The longitudinal data from Iluka, New South Wales, suggested that mild focal lesions became generalised and severe over about $4 \mathrm{~d}$.

The clinical signs of the disease correlated well with the pathology. The gill lesions were of sufficient severity to compromise gas exchange, as evidenced by the relative hypoxaemia and hypercapnea in affected fish. We also demonstrated respiratory and metabolic aci- dosis, but other disturbances of ionic regulation and failure of excretion of wastes may also have contributed to the pathogenesis of the disease. A range of lesion severities was seen in affected fish as clinical signs and death were precipitated by external stressors which would be expected to vary from place to place. Subclinically affected fish were thus in compensated respiratory and/or osmoregulatory failure prior to the stress.

As the pathology was relatively consistent across the geographic range of the mortality event, a common aetiology is suggested. The gills of teleosts are susceptible to a wide range of insults and the lesions that result are often not specific or even indicative of their aetiology. Common lesions such as lamellar oedema, epithelial degeneration and necrosis, epithelial hypertrophy and hyperplasia and lamellar fusion may be due to environmental, infectious, nutritional and other causes (Eller 1975, Mallatt 1985). Furthermore there is little information on the responses of different species of fish to similar insults. However, the morphogenesis of the lesions in pilchard gills from focal to generalised and the development of lamellar fusion through contact of attenuated cell extensions followed by hyperplasia were remarkable and do not appear to have been described before (Eller 1975, Gardner 1975, Daye \& Garside 1976, Daoust et al. 1984, Chevalier et al. 1985, Mallatt 1985, Karlsson-Norrgren et al. 1986a, b, Ferguson 1989, Roberts 1989). The lack of mucous cell activity, epithelial degeneration and necrosis and microbial pathogens visible at the light microscope level were also notable.

As the epizootic was thought by many observers to be environmentally mediated, some discussion of this is warranted. Environmentally mediated chemical and toxicological insults cause generalised rather than focal changes in gills and these become more severe with time; lamellar fusion occurs by contact of cell processes from plump epithelial cells which may already be hyperplastic (Daoust et al. 1984), changes clearly dissimilar to those in affected pilchards. Chloride cell hyperplasia may occur in response to aluminium toxicity and exposure to acid water (KarlssonNorrgren et al. 1986a, b) but is not accompanied by the other inflammatory changes seen in pilchards. The pathological findings in pilchards also were not consistent with exposure to an algal bloom: there was little or no lamellar oedema or epithelial cell degeneration (Jones et al. 1982, Roberts et al. 1983, Endo et al. 1985. Toyoshima et al. 1985); the inflammation and hyperplasia was more severe than that which occurs in response to ichthyotoxic algae (Chang et al. 1990); algae that cause asphyxiation were not present in the interlamellar spaces or attached to secondary lamellae (Jones \& Rhodes 1994); and there was no excess 
mucus, oedema, haemorrhage, epithelial cell necrosis, siliceous fragments or foreign body reactions and proliferating epithelium did not retain polygonal morphology as is seen in mortality events due to physical irritation by siliceous diatoms (Ferguson 1989. Speare et al. 1989, Yang \& Albright 1992, Kent et al. 1995). The absence of relevant pathological findings was consistent with the lack of evidence of an environmental insult. No single oceanograpkic disturbance was reported across Australia and New Zealand (Griffin et al. 1997), the spread of the disease was not impeded or assisted by prevailing currents or storms and it is impossible to conceive of a man-made toxin affecting such a wide region of the sea.

The epizootiological pattern was consistent with an infectious aetiology. Furthermore a herpesvirus was consistently present in affected fish, was found associated with early lesions several days before the onset of mortality and was absent from healthy fish ahead of the mortality front. Other candidate pathogens were not present in early lesions, were found inconsistently or were present in low numbers (Table 1). Therefore the herpesvirus is proposed as the aetiological agent. The nature and morphogenesis of this virus are described in the companion paper (Hyatt et al. 1997). Many herpesviruses have been identified in fishes and the majority have been associated with epithelial proliferations (Wolf 1988, Hedrick \& Sano 1989). Some appear to have caused epizootic mortality (Iida et al. 1989, McAllister \& Herman 1989) and at least one has been associated with hyperplasia of the branchial epithelium (Watson et al. 1995).

The nature of the gill pathology also enabled microbial agents other than the herpesvirus to be excluded. Filamentous bacteria were observed in some severely affected gills but they were present in insufficient numbers to warrant consideration of bacterial gill disease. This condition was also ruled out by the absence of mucous cell hyperplasia, epithelial oedema, degeneration and necrosis (Speare \& Fergusson 1989, Speare et al. 1991). Although large numbers of amoebae were present on the gills of some affected fish, the lesions in these fish were not consistent with amoebic gill disease in which there is typically mucous cell hyperplasia (Kent et al. 1988, Roubal et al. 1989, Munday et al. 1990) with a multifocal or segmental and nodular epithelial reaction (Ferguson 1989, Roberts 1989).

The epizootiological data suggest that the disease spread from an origin near Anxious Bay in South Australia at a rate of about $30 \mathrm{~km} \mathrm{~d} \mathrm{~d}^{-1}$ Spread was often in directions contrary to prevailing currents. While northward migrations of pilchards along the New South Wales coast are known to occur in winter and spring (Fletcher 1990), tagging studies of Chilean pilchard Sardinops sagax have shown a speed of about $5.4 \mathrm{~km} \mathrm{~d}^{-1}$ (Torres et al. 1985). Thus it is not possible for currents or pilchard movements to account for the direction or rate of spread of the mortality front, which suggests that the spread in Australia involved a vector such as a piscivorous mammal or bird. Although there may have been separate foci of disease in New Zealand, the spread in the northeast also cannot be explained by movements of pilchards or currents alone. In both Australia and New Zealand there is overlap in the distribution of pilchards with that of some seabirds such as shearwaters but particularly the Australasian gannet Morus serrator (Blakers et al. 1984, Marchant \& Higgins 1990). Many observers noted birds feeding from or near affected schools of pilchards during the epizootic in both Australia and New Zealand. Several viruses of fishes are known or suspected to be transmitted by piscivorous birds through regurgitation of infected fish or passage of viable virus in faeces (Olesen \& VestergardJørgensen 1982, Peters \& Neukirch 1986, Whittington et al. 1996). The pilchard comprises a significant proportion of the diet of gannets in both Australia and New Zealand (Wingham 1985, Norman \& Menkhorst 1995). Gannets may have been responsible for some of the spread of the disease in New Zealand as they were seen eating pilchards along the mortality front and arrived in Wellington Harbour a few days before the pilchard mortalities began there. Gannets were also seen in Western Australian waters associated with the mortality event but were not noticed during sampling off the coast of New South Wales at Port Stephens or Iluka.

The lack of history of large-scale mortalities in pilchards in Australian waters, the focal origin of the outbreak, and the dramatic spread of the disease around continental Australia are consistent with the theory that the epizootic was due to an infectious disease agent that was not present before in Australian pilchard stocks. The recognition that discharge of ballast water from commercial shipping and the importation of baitfish are possible mechanisms for the introduction of putative exotic microbial pathogens into Australian coastal waters predates the pilchard epizootic (Munday et al. 1994, Humphrey 1995). Coincidentally over 10000 tonnes per annum of Sardinops sagax and a mix of bycatch species including other clupeoids have been imported without quarantine inspection from California, Peru, Chile or Japan and fed out to sea-caged southern bluefin tuna in South Australia. Meyers et al. (1994) have already suggested that frozen herring bait is a potential source for the dissemination of viral haemorrhagic septicaemia virus, which survives 2 conventional freeze-thaw cycles, and suggested that the European strain of virulent VHSV arose through the habit of feeding frozen bait to hatch- 
ery fish. Bacterial fish pathogens are also known to survive in frozen clupeoids (Yasunaga 1982). As noted above migratory birds may also be a means of introduction of exotic microbial fish pathogens into Australian waters.

The possibility that the epizootic was due to activation of a latent herpesvirus infection in Australian pilchards is remote given the lack of evidence of a primary disease event or an environmental trigger. Acquisition of infection from another marine host also seems unlikely given that herpesviruses are mostly host specific. There is also the possibility of a new/emerging virus disease. These issues are discussed further in Hyatt et al. (1997). Work is underway in Australia to purify the herpesvirus from affected gills and prepare specific reagents for its detection, while in New Zealand an attempt will be made to transmit the virus experimentally to healthy pilchards.

The economic impact of this epizootic in pilchards is not yet known. There is a small but significant pilchard fishery in Western Australia and single pilchard fishers in New South Wales and New Zealand. The ecological impacts are also uncertain. The data suggest that some schools may have escaped the effects of the disease but it is reasonable to assume that the loss of pilchard biomass will cause, at least temporarily, measurable effects in populations of birds, mammals, fish, squid and other aquatic organisms that include the pilchard as an important dietary component.

Acknowledgements. The authors thank fjeld staff and commercial fishers who undertook specimen collection on our bchalf, often in adverse weather conditions: Bob Swan (lluka, New South Wales), John Matthews (New South Wales Fisheries), John Holdsworth (New Zealand Ministry of Fisheries) and Lincoln McKenzie (Cawthron Institute, New Zealand). Grant Rawlın (Agriculture Victoria) kindly supplied sections of gill from Merimbula. We also thank laboratory staff for skilled assistance: Christine Kearns, Maria Hardy, Angela Crowe, Christine Hornitzky, Craeme Fraser (New South Wales Agriculture); Paul Taylor, Brett Wesney, Steve Mercer, Peter Gerring, Neil Bagley (NIWA, New Zealand); Tina Thorne, Paul Hillier, Trevor Ellis, Rick Fletcher and Stuart Blight (Western Australia Department of Fisheries and Western Australia Department of Agriculture). Ian Tompson, Chemical Pathology, Wellington Hospital undertook the blood gas analysis. Sandy Bartle, National Museum of New Zealand, kindly provided information on seabirds. The agencies of the authors, MAF Regulatory Authority and New South Wales Fisheries, provided financial assistance.

\section{LITERATURE CITED}

Blakers M, Davies SJJF, Reilly PN (1984) The atlas of Australian birds. University of Melbourne Press, Melbourne

Chang FH, Anderson C, Boustead NC (1990) First record of a Heterosigma (Raphidophyceae) bloom with associated mortality of cage reared salmon in Big Glory Bay, New Zealand. NZ J Mar Freshwat Res 24:461-469
Chevaluer G, Gauthier L, Moreau G (1985) Histopathological and electron microscopic studies of gills of brook trout, Salvelinus fontinalis, from acidified lakes. Can J Zool 63 : $2062-2070$

Copas C (1982) Mystery fish deaths. Professional Fisherman. The Voice of Australasian Fishing Industry 4(6):24

Daoust PY, Wobeser G. Newstead JD (1984) Acute pathological effects of inorganic mercury and copper in gills of rainbow trout. Vet Pathol 21:93-101

Daye PG, Garside ET (1976) Histopathologic changes in superficial tissues of brook trout Salvelinus fontinalis (Mitchell), exposed to acute and chronic levels of $\mathrm{pH}$. Can J Zool 54:2140-2155

Eller LL (1975) Gill lesions in freshwater teleosts. In: Ribelin WE, Migaki G (eds) The pathology of fishes. University of Wisconsin Press, Wisconsin, p 305-330

Endo M, Sakai T, Kuroki A (1985) Histological and histochemical changes in the gills of yellowtail exposed to the Raphidphycean flagellate Chattonella marina. Mar Biol 87: $193-197$

Ferguson HW (1989) Systemic pathology of fish. Iowa State University Press, Ames

Fletcher WJ (1990) A synopsis of the biology and the exploitation of the Australasian pilchard Sardinops neopilchardus (Steindachner). Part 1: Biology. Fisheries Research Report, Fisheries Department of Western Australia 88:1-45

Gardner GR (1975) Chemically induced lesions in estuarine or marine teleosts. In: Ribelin WE, Migaki G (eds) The pathology of fishes. University of Wisconsin Press, Wiscon$\sin , \mathrm{p} 657-693$

Graham DH (1954) A treasury of New Zealand fishes. AH \& AW Reed, Wellington

Griffin DA, Thompson PA, Bax NJ, Bradford RW, Hallegraeff GM (1997) The 1995 pilchard mass mortality: no role found for physical nor biologucal oceanographic factors in Australia. Mar Freshwat Res (in press)

Hedrick RP, Sano T (1989) Herpesviruses of fishes. In: Ahne W. Kurstak E (eds) Viruses of lower vertebrates. SpringerVerlag, Berlin, p 161-170

Humphrey JD (1995) Australian quarantine policies and practices for aquatic animals and their products: a review for the scientific working party on aquatic animal quarantine. Bureau of Resource Sciences, Canberra

Hyatt AD, Hine PM, Jones JB, Whittington RJ, Kearns C, W1se TG, Crane MS, Williams LM (1997) Epizootic mortality in the pilchard (Sardinops sagax neopilchardus) in Australia and New Zealand in 1995. II Identification of a herpesvirus within the gill epithelium. Dis Aquat Org 28:17-29

Lida Y, Masumura K, Nakai T, Sorimachi M, Matsuda H (1989) A viral disease in larvae and juveniles of the Japanese flounder Paralichthys olivaceus. J Aquat Anim Health 1 : $7-12$

Inglis V, Roberts RJ, Bromage NR (1993) Epitheliocystis and salmonid rickettsial septicaemia. In: Bacterial diseases of fish. Blackwell Scientific Publications, London, p 237-254

Jones JB, Rhodes LL (1994) Suffocation of pilchards (Sardinops sagax) by a green microalgal bloom in Wellington Harbour, New Zealand. NZ J Mar Freshwat Res 28: $379-383$

Jones KJ, Ayres P, Bullock AM, Roberts RJ, Tett P (1982) A red tide of Gyrodinium aureolum in sea lochs of the Firth of Clyde and associated mortality of pond-reared salmon. J Mar Biol Assoc UK 62:771-782

Karlsson-Norrgren L, Bjorklund I, Ljungberg $O$, Runn $P$ (1986a) Acid water and aluminium exposure: experimentally induced gill lesions in brown trout, Salmo trutta $\mathrm{L}$. J Fish Dis 9:11-25 
Karlsson-Norrgien L, Dickson W, Ljungberg O, Runn P (1986b) Acid water and aluminium exposure: gill lesions and aluminium accumulation in farmed brown trout. Salmo trutta L. J Fish Dis 9:1-9

Kent ML, Sawyer TK, Hedrick RP (1988) Paramoeba pemaquidensis (Sarcomastigophora: Paramoebidae) infestation. of the gills of coho salmon Oncorhynchus kisutch reared in sea water. Dis Aquat Org 5:163-169

Kent ML, Whyte JNC, LaTrace C (1995) Gill lesions and mortality in seawater pen-reared Atlantic salmon Salmo salar associated with a dense bloom of Skeletonema costatum and Thalassiosira species. Dis Aquat Org 22:77-81

Langdon JL (1991) Myoliquefaction post-mortem ('milky flesh') due to Kudoa thyrsites (Gilchrist) (Myxosporea: Multivalvulida) in mahi mahi, Coryphaena hippurus L. $J$ Fish Dis 14:45-54

Levine ND (1983) The genera Barrouxia, Defretinella, and Goussia of the coccidian family Barrouxiidae (Protozoa, Apicomplexa). J Protozool 30:542-547

Mallatt J (1985) Fish gill structural changes induced by toxicants and other irritants: a statistical review. Can J Fish Aquat Sci 42:630-648

Marchant S, Higgins PJ (1990). Handbook of Australian, New Zealand and Antarctic birds, Vol 1 Ratites to ducks. Oxford University Press, Melbourne, p 751-762

McAllister PE, Herman RL (1989). Epizootic mortality in hatchery-recred lake trout Salvelinus namaycush caused by a putative virus possibly of the herpesvirus group. Dis Aquat Org 6:113-11.9

Meyers TR, Short S, Lipson K, Batts WN, Winton JR, Wilcock J, Brown E (1994) Association of viral haemorrhagic septicaemia virus with epizootic haemorrhages of the skin in Pacific herring Clupea harengus pallasi from Prince William Sound and Kodiak Island, Alaska, USA. Dis Aquat Org 19:27-37

Munday BL, Clark A, Hine M, Lester R, Whittington RJ (1994) An epidemiological review of possible introductions of fish diseases, Northern Pacific seastar and Japanese kelp through ship's ballast water. Australian Quarantine and Inspection Service Ballast Water Research Series Report No. 3. Australian Government Publishing Service, Canberra

Munday BL, Foster CK, Roubal FR, Lester RJG (1990) Paramoebic gill infection and associated pathology of Atlantic salmon, Salmo salar, and rainbow trout, Salmo gairdneri, in Tasmania. In: Perkins FO, Cheng TC (cds) Pathology in marine science. Academic Press, San Diego, p 215-222

Norman FI, Menkhorst PW (1995) Aspects of the breeding and feeding ecology of the Australasian gannet Morus serrator in Port Phillip Bay, Victoria, 1988-1992. Emu 95: $23-40$

Olesen NJ, Vestergard Jørgensen PE (1982) Can and do herons serve as vectors for Egtved virus? Bull Eur Assoc Fish Pathol 3;48

Responsible Subject Editor: F M. Hetrick, College Park Maryland, USA
Peters F, Neukirch M (1986) Transmission of some fish pathogenic viruses by the heron, Ardea cinerea. J Fish Dis 9 $539-544$

Roberts RJ (1989) Fish pathology. Bailliere Tindall, London, p 467

Roberts RJ, Bullock AM, Turner M, Jones K, Tett P (1983) Mortalities of Salmo gardneri exposed to cultures of Gyrodinium aureolum. J Mar Biol Assoc UK 63:741-743

Roubal FR, Lester RJG. Foster CK (1989) Studies on cultured and gill-attached Paramoeba sp. (Gymnamoebae: Paramoebidae) and the cytopathology of paramoebic gill disease in Atlantic salmon, Salmo salar L., from Tasmania. J Fish Dis 12:481-492

Sindermann CJ (1990) Principal diseases of marine fish, Vol 1, 2nd edn. Academic Press, New York, p 375-397

Speare DJ, Brackett J, Ferguson HW (1989) Sequential pathology of the gills of Coho salmon with a combined diatom and microsporidian gill infection. Can Vet $\mathrm{J}$ 30: $571-575$

Speare DJ, Ferguson HW (1989) Clinical and pathological features of common gill diseases of cultured salmonids in Ontario. Can Vet J 30:882-887

Speare DJ, Ferguson HW, Beamish FWM, Yager JA, Yamashiro S (1991) Pathology of bacterial gill disease: sequential development of lesions during natural outbreaks of disease. J Fish Dis 14:21-32

Torres GA, Martinez JC. Oliva LJ (1985) Migrations of Chilean pilchard in the southeast Pacific, during El Niño 1982-83 phenomenon and in 1984. Invest Pesq (Chile) $32: 95-100$

Toyoshima T, Ozaki HS, Shimada M, Okaichi T, Murakami TH (1985) Ultrastructural alterations on chloride cells of the yellowtail Seriola quinqueradiata following exposure to the red tide species Chattonella antiqua. Mar Biol 88: $101-108$

Watson LR, Yun SC, Groff JM, Hedrick RP (1995) Characteristics and pathogenicity of a novel herpesvirus isolated from adult and subadult white sturgeon Acipensor transmontanus. Dis Aquat Org 22:199-210

Whittington RJ, Kearns C, Hyatt AD, Hengstberger S, Rutzou $\mathrm{T}$ (1996) Spread of epizootic haematopoietic necrosis virus (EHNV) in redfin perch Perca fluviatilis in southern Australia. Aust Vet J 73:112-114

Wingham EJ (1985) Food and feeding range of the Australasian gannet Morus serrator (Gray). Emu 85:231-239

Wolf K (1988) Fish viruses and fish viral diseases. Cornell University Press, Ithaca

Yang CZ, Albright LJ (1992) Effects of the harmful diatom Chaetoceros concavicornis on respiration of rainbow trout Oncorhynchus mykiss. Dis Aquat Org 14:105-114

Yasunaga N (1982) Occurrence of Streptococcus sp., a pathogen of cultured yellowtail, in muscle of sardine for diets. Fish Pathol 17:195-198

Manuscript first received: May 7, 1996

Revised version accepted: September 24, 1996 